Paedagogia Christiana

2/30 (2012) - ISSN 1505-6872

Jacek J. Bleszyński*

Anita Rodkiewicz-Ryżek**

Toruń

\title{
Ochrona praw dziecka w świetle standardów polskich i międzynarodowych
}

\author{
My, dorośli, na wiele potrzebnych \\ nam rzeczy możemy poczekać. \\ Dziecko nie może. Właśnie teraz \\ formułują się jego myśli, rozwija umysł. \\ Nie możemy mu powiedzieć: \\ Jutro.
}

G. Mistral

\section{Wprowadzenie}

We współczesnym świecie zasada, że każde dziecko ma prawo do szacunku, troskliwej opieki i traktowania jak każda pełnoprawna osoba, przez większość państw nie jest już kwestionowana. Mimo wielu podpisanych i ratyfikowanych konwencji, traktatów nadal zdarzają się jednak nadużycia wobec najmłodszych, których najłatwiej można skrzywdzić, gdyż są słabi, bezbronni, niewinni, naiwni. Przemoc, jak wskazuje większość teorii psy-

* Dr hab. Jacek J. Błeszyński, prof. UMK, jest kierownikiem Pracowni Badań nad Niepełnosprawnością Złożoną w Katedrze Pedagogiki Specjalnej na Wydziale Nauk Pedagogicznych Uniwersytetu Mikołaja Kopernika w Toruniu.

** Dr Anita Rodkiewicz-Ryżek jest absolwentką prawa i pedagogiki na Uniwersytecie Mikołaja Kopernika w Toruniu, doktorem nauk humanistycznych w dziedzinie pedagogiki, pracuje na Wydziale Nauk Pedagogicznych UMK. 
chologicznych i antropologicznych, ma swoje źródła w pierwotnych i prymitywnych odruchach, które kiedyś pomagały w przetrwaniu - a tym samym decydowały również o przedłużeniu gatunku. Zachowania te są nadal często promowane $\mathrm{w}$ tradycjach, kulturach (np. corrida w Hiszpanii, inicjacje w Afryce), są kultywowane i akceptowane w różnych formach, także w samym prawie ${ }^{1}$, które jest odzwierciedleniem rozwoju społecznego.

Walka z przemocą wobec dzieci ukierunkowana jest na demokratyzację stosunków wewnątrzrodzinnych, a tym samym z instytucją patriarchalnej rodziny. Można uznać, iż jest wpisana w ruch inkluzji, jaki jest obecnie powszechnie wprowadzany w różnych sferach życia społecznego w Polsce, Europie i na świecie. W obecnej tendencji terminologicznego ujęcia problemu dotyczy wszystkich osób, często określanych terminem „Inny”, jako znacznika odmienności, różnicowania, a tym samym eliminacji lub ograniczania praw przysługujących w społeczeństwie (ekskluzja - jako wyłączanie $)^{2}$. W przypadku rodziny przez wieki dominował pogląd o niezaprzeczalnej władzy ojcowskiej. Jeszcze w IV wieku naszej ery ojciec miał prawo decydowania o życiu i śmierci członków rodziny. W jego gestii znajdowały się wszelkie działania w obrębie rodziny - jak również rodzicielstwa zastępczego $^{3}$. Jego władza, określona przez teksty prawne, była nieograniczona. Wobec dzieci dozwolone były kary cielesne, pozbawienie majątku czy nawet wydanie nakazu opuszczenia rodziny ${ }^{4}$.

Ewolucja prawa w kierunku ochrony życia i praw dziecka postępowała bardzo powoli. Prekursorem zakazu stosowania kar cielesnych była Szwecja. W tym państwie od 1 lipca 1979 roku zaczęło obowiązywać prawo zakazujące fizycznego karania dzieci. Ustawowy zakaz bicia stopniowo wprowadziły między innymi Austria, Dania, Norwegia, Cypr i Włochy ${ }^{5}$.

$\mathrm{Z}$ upływem lat dziecko zaczęto obejmować coraz większą ochroną, jednak żadne akty prawne nie mogą nakazać dorosłym kochania dziecka czy okazywania mu miłości, gdyż byłyby to martwe przepisy. Sa jednak sfery życia, w które prawo powinno ingerować. Jeśli dziecko jest krzywdzone

${ }^{1}$ M. Płatek, Prawne korzenie przemocy wobec dziecka, „Niebieska Linia” 6 (2001), s. 14 .

2 J. J. Błeszyński, Inkluzja/ekskluzja jako wyzwanie społeczne w odniesieniu do edukacji specjalnej w Polsce, w: M. Dycht, L. Marszałek (red.), Inkluzja i ekskluzja społeczna osób z niepetnq sprawnościq. Wspótczesne konteksty i kontrowersje pedagogiki wspierajacej, Warszawa 2009; J. Oleksy, Edukacja inkluzyjna - pomiędzy szansq i zagrożeniem, w: Z. Gajdzica (red.), Uczeń z niepetnosprawnościq w szkole ogólnodostępnej, Sosnowiec 2011.

3 J. J. Błeszyński, Kluczowe zagadnienia przysposobienia i funkcjonowania rodzin adopcyjnych, Kraków 2010.

${ }^{4}$ M. Płatek, dz. cyt., s. 14.

5 Tamże. 
w domu, w szkole, na ulicy czy w innym środowisku, tam w jego obronie zawsze powinno stanąć państwo ${ }^{6}$.

Steven J. Breiner odniósł się do problemu krzywdzenia dzieci, zauważając, iż „Krzywdzenie dzieci jest fenomenem, który jest w naszym świecie powszechny od czasu, gdy ludzie zaczęli rejestrować swoją historię"7. Philippe Ariès dowiódł, iż do XVIII wieku wciąż jeszcze nie rozumiano odrębności i specyfiki dziecka. Dzieciństwo traktowano jako okres słabości fizycznej i moralnej, które należy potraktować surowym wychowaniem ${ }^{8}$, co wynika z konserwatywnej interpretacji Biblii, a można zaobserwować również współcześnie w najbardziej radykalnych ruchach chrześcijańskich, na przykład w USA przykładem mogą być Mormoni.

Analizując prawa człowieka w aspekcie historycznym, można uznać, iż były wynikiem zainteresowania się istotą egzystencji człowieka, jak również odpowiedzią na kształtujące się w Europie w dobie oświecenia nowe struktury społeczne. Pierwszy raz terminu tego użyto w Bill of Rights Virginii z 1776 roku w utylitarnym rozumieniu, jako praw przysługujących każdemu człowiekowi, bez względu na przynależność państwową czy pozycję społeczną 9 .

Obowiązująca Konstytucja Rzeczypospolitej Polskiej stanowi, że prawa i wolności przysługują każdemu, kto znajduje się pod władzą RP (art. 37 Konstytucji RP) ${ }^{10}$. Jednak warunkiem posiadania ich przez osobę są prawne gwarancje ochrony. Samo proklamowanie praw człowieka w akcie normatywnym nie przesądza, że prawa te będą respektowane. Należy wprowadzić odpowiednie mechanizmy i środki, chroniące osobę przed ograniczeniami przysługujących jej praw ${ }^{11}$. Termin ,,prawa dziecka”, podobnie jak ,„prawa człowieka", bywa powszechnie używany i posiada zróżnicowany kontekst znaczeniowy. W takim ujęciu prawa dziecka są jednym z typów praw człowieka, gdzie dziecko jest pełnym podmiotem tych praw. Ograniczenia wynikające $\mathrm{z}$ rozwoju i możliwości funkcjonalnych (tak intelektualnych, jak i fizycznych) powinny być impulsem do objęcia szczególną troską i opieką,

${ }^{6}$ M. Szymańczak, Pojęcie krzywdzenia dzieci, „Niebieska Linia” 1 (1999), http://www. pismo. niebieskalinia.pl/index.php?id=239 (20.06.11)

7 Tamże.

8 Tamże.

9 Zob. B. Banaszak, A. Preisner (red.), Prawa i wolności obywatelskie w Konstytucji $R P$, Warszawa 2002, s. 15 .

${ }_{10}$ Zob. Konstytucja Rzeczypospolitej Polskiej, Dz. U. z 1997, nr 78, poz. 483.

${ }^{11}$ Zob. B. Banaszak, A. Bisztyga, K. Complak, M. Jabłoński, R. Wieruszewski, System ochrony praw człowieka, Zakamycze 2005, s. 17. 
na przykład niepełnosprawność nie może być powodem ograniczenia ochrony, lecz wręcz przeciwnie ${ }^{12}$.

Prawa człowieka sformułowane w aktach prawnych odpowiadają potrzebom każdej jednostki ludzkiej, która może domagać się od władzy państwowej ich zaspokojenia. Dziecko jednak nie jest w stanie samodzielnie domagać się respektowania swych praw. Prawa najmłodszych mogą być realizowane jedynie przez działania dorosłych ${ }^{13}$.

\section{Ochrona praw dziecka w aktach prawnych o charakterze ogólnym}

Szczególną rolę w walce o ochronę praw człowieka przypisujemy Organizacji Narodów Zjednoczonych. W 1945 roku w San Francisco przyjęto Kartę Narodów Zjednoczonych. W Preambule państwa zobowiązały się „przywrócić wiarę w podstawowe prawa człowieka, w godność i wartość człowieka, równość praw mężczyzn i kobiet oraz narodów wielkich i małych $[\ldots]^{\prime \prime 14}$.

Zgromadzenie Ogólne ONZ 10 grudnia 1948 roku ogłosiło Powszechną Deklaracje Praw Człowieka ${ }^{15}$. Ostatni punkt Preambuły stanowi:

Zgromadzenie Ogólne ogłasza uroczyście niniejszą Powszechną Deklarację Praw Człowieka jako wspólny najwyższy cel wszystkich narodów, aby wszyscy ludzie i wszystkie organy społeczeństwa dążyły w drodze nauczania i wychowania do rozwijania i poszanowania tych praw i wolności i aby zapewniły za pomocą postępowych środków o zasięgu krajowym i międzynarodowym powszechne i skuteczne uznanie i stosowanie tej deklaracji $[\ldots]^{16}$.

Kolejne artykuły dokumentu wskazują na poszczególne prawa człowieka. Art. 1 potwierdza fundamentalną zasadę, iż „wszyscy ludzie rodzą się wolni i równi pod względem swej godności i swych praw. Są oni obdarze-

12 Zob. P. Jaros, Ochrona praw dziecka po przystapieniu do UE, w: M. Potapowicz, M. Krauzowicz, P. Przybylski (red.), Prawa dziecka po przystapieniu do UE. Materiaty z konferencji Rzecznika Praw Obywatelskich, Warszawa 2004, s. 13.

${ }_{13}$ Zob. T. Smyczyński, Ochrona praw człowieka, R. Wieruszewski (red.), Prawa człowieka. Model prawny, Wrocław, Warszawa, Kraków 1991, s. 113.

${ }_{14}$ Zob. Karta Narodów Zjednoczonych, Dz. U. 1947, nr 23, poz. 90.

15 Zob. M. Andrzejewski, Prawna ochrona rodziny, Warszawa 1999, s. 140.

16 Zob. Powszechna Deklaracja Praw Człowieka, w: B. Gronowska, T. Jasudowicz, C. Mik (oprac.), Prawa człowieka. Wybór dokumentów międzynarodowych, Torun 1999, s. $12-20$. 
ni rozumem i sumieniem oraz powinni postępować w stosunku do siebie wzajemnie w duchu braterstwa" ${ }^{17}$. Deklaracja wskazuje również, że ,każdy człowiek ma obowiązki wobec społeczności, w której to jedynie jest możliwy swobodny i pełny rozwój jego osobowości” (art. 29 ust. 1) ${ }^{18}$. Powszechna Deklaracja Praw Człowieka zawiera przesłanie, które kieruje do każdego człowieka, w tym dzieci ${ }^{19}$.

Rezolucją Zgromadzenia Ogólnego z dnia 16 grudnia 1966 roku został przyjęty Międzynarodowy Pakt Praw Obywatelskich i Politycznych. Polska ratyfikowała ten dokument 18 lutego 1977 roku. Artykuł 23 Paktu stanowi, iż rodzinie, jako naturalnej i podstawowej komórce społeczeństwa, należy się ochrona ze strony społeczeństwa i państwa. Dokument zakazuje dyskryminacji dziecka ze względu na rasę, kolor skóry, płeć, język, religię, pochodzenie społeczne i sytuację majątkową oraz zapewnia prawo do korzystania ze środków ochrony , jakich wymaga status małoletniego, ze strony rodziny społeczeństwa i Państwa" (art. 24 ust. 1) ${ }^{20}$.

W dniu 16 grudnia 1966 r. uchwalono Międzynarodowy Pakt Praw Gospodarczych, Socjalnych i Kulturalnych ${ }^{21}$. Polska ratyfikowała go 18 marca 1977 roku. Dokument stanowi także o potrzebie ochrony dzieci i młodzieży oraz zapewnia im opiekę, bez dyskryminacji ze względu na pochodzenie $\mathrm{i}$ inne przyczyny. Jak wynika z Paktu, państwo ma obowiązek ochraniać młodych pracowników przed wyzyskiem ekonomicznym. Bezwzględnie zakazana jest praca szkodliwa dla ich moralności, zdrowia i życia lub zagrażająca ich rozwojowi (art. 10 ust. 3).

Ochrona praw dziecka przestała być postulatem, który należy jedynie do obszaru zainteresowań etyki. W związku z narastającym zjawiskiem przemocy zyskała ona rangę prawną ${ }^{22}$. Każde dziecko ma prawo do szacunku i troskliwej opieki. Gwarantują to umowy międzynarodowe, ratyfikowane przez większość krajów na całym świecie.

17 Tamże.

18 Tamże.

19 Zob. M. Piechowiak, Czym Sa prawa dziecka?, w: M. Potapowicz, M. Krauzowicz, P. Przybylski (red.), Prawa dziecka po przystapieniu do UE. Materiały z konferencji Rzecznika Praw Dziecka, Warszawa 2004, s. 22-23.

20 Zob. Międzynarodowy Pakt Praw Obywatelskich i Politycznych, w: Gronowska, T. Jasudowicz, C. Mik (oprac.), dz. cyt., s. 22-47.

${ }_{21}$ Zob. Międzynarodowy Pakt Praw Gospodarczych, Socjalnych i Kulturalnych, w: B. Gronowska, T. Jasudowicz, C. Mik (oprac.), dz. cyt., s. 62-75.

22 Zob. M. Andrzejewski, dz. cyt., s. 149. 


\section{Standardy o charakterze specjalnym}

Międzynarodowy Związek Pomocy Dzieciom ogłosił w 1924 roku Deklarację Praw Dziecka, powszechnie zwaną Genewską. Ważne znaczenie miała Preambuła, w której zapisano, że „mężczyźni i kobiety wszystkich narodowości uznają że ludzkość powinna dać dziecku wszystko, co posiada najlepszego, i stwierdzaja, że ciążą na nich, bez względu na rasę, narodowość i wyznanie wyspecyfikowane następnie obowiązki" ${ }^{23}$. Po raz pierwszy postawiono przed ludźmi obowiązek dania dziecku wszystkiego, co posiadają najlepszego. Dostrzeżono w końcu podmiotowość dziecka i potrzebę ochrony jego podstawowych praw.

Ważnym krokiem było ogłoszenie w 1959 roku przez Zgromadzenie Ogólne ONZ Deklaracji Praw Dziecka. Zawiera ona dziesięć punktów, które potwierdzają tezę, że każdemu dziecku należy się opieka i ochrona należnych mu praw. W Deklaracji pierwszy raz pojawiło się pojęcie interesu dziecka ${ }^{24}$.

Ważną rolę w walce o ochronę praw dziecka odegrała Polska, która 7 lutego 1978 roku zgłosiła projekt Konwencji o Prawach Dziecka. Zgromadzenie Ogólne przyjęło ją 20 listopada 1989 roku. Często jest ona nazywana światową konstytucją praw dziecka. Podkreślono w niej potrzebę traktowania dzieci jako samodzielnych podmiotów oraz konieczność szczególnej opieki i ochrony prawnej (art. 3) ${ }^{25}$. Konwencja Praw Dziecka (KPD) jest pierwszym dokumentem międzynarodowym, który zawiera tak szeroki katalog praw dziecka. Deklaracje z 1924 i 1959 roku podkreślały przede wszystkim prawa dziecka do opieki i ochrony, natomiast Konwencja zawiera postanowienia dotyczące jego praw i wolności osobistych ${ }^{26}$. W Konwencji zdefiniowano dziecko (art.1) jako „każdą istotę ludzką w wieku poniżej osiemnastu lat, chyba że zgodnie z prawem odnoszącym się do dziecka uzyska ono wcześniej pełnoletniość"

Państwa, które ratyfikowały Konwencję, zobowiązały się do zagwarantowania i przestrzegania praw i wolności dziecka, bez względu na płeć, rasę, kolor skóry, język, religię, poglądy polityczne, status majątkowy, niepełnosprawność, cenzus urodzenia lub jakąkolwiek inną sytuację (art. 2). Kon-

23 J. Szymańczak, Konwencja o Prawach Dziecka ONZ. Uwagi o realizacji konwencji przez Rzeczypospolitq Polskq, http://biurose.sejm.gov.pl (20.06.2011).

${ }^{24}$ Zob. J. Białocerkiewicz, Prawo międzynarodowe publiczne. Zarys wykładu, Olsztyn 2005, s. 307.

${ }^{25}$ Zob. M. Andrzejewski, dz. cyt., s. 144.

26 Zob. E. Czyż, Prawa dziecka, Warszawa 2002, s. 13-14.

${ }^{27}$ Konwencja o Prawach Dziecka, Dz. U. z 1991 r., nr 120, poz. 526. 
wencja odwołuje się również do interesu dziecka, który stanowi podstawową przesłankę interpretacyjną w czynnościach podejmowanych na rzecz dziecka (art. 3, 21) ${ }^{28}$. Nawiązuje do innych dokumentów międzynarodowych: Genewskiej Deklaracji Praw Dziecka (1924 r.), Deklaracji Praw Dziecka ONZ (1959 r.), Powszechnej Deklaracji Praw Człowieka (1948 r.), Międzynarodowego Paktu Praw Obywatelskich i Politycznych (1966 r.) oraz Międzynarodowego Paktu Praw Gospodarczych, Społecznych i Kulturalnych (1966 r.), ale znalazły się w niej też prawa, które nie mają odpowiedników w wymienionych dokumentach. Są to: prawo do obywatelstwa (art. 7), ochrona przed nielegalnym transferem za granicę (art. 11), prawo do najwyższego poziomu zdrowia i udogodnień w zakresie leczenia chorób i rehabilitacji zdrowotnej (art. 24), ochrona przed wyzyskiem seksualnym (art. 34), ochrona przed innymi formami wyzysku (art. 30). Artykuł 19 dotyczy ochrony dziecka przed „wszelkimi formami przemocy fizycznej bądź psychicznej, krzywdy lub zaniedbania bądź złego traktowania lub wyzysku, w tym wykorzystywania w celach seksualnych". W art. 37 państwa, które ratyfikowały Konwencję, zobowiązały się do ochrony dzieci przed torturami bądź okrutnym, nieludzkim czy poniżającym traktowaniem lub karaniem. Art. 32 i 36 stanowią o ochronie przed wszelkimi formami wyzysku oraz przed wykonywaniem pracy, która może być niebezpieczna. Konwencja chroni również najmłodszych przed narkomanią (art. 33), uprowadzeniem i handlem (art. 35) oraz przed aktywnym uczestnictwem w konfliktach zbrojnych (art. 38) ${ }^{29}$.

W roku 2000 Zgromadzenie Ogólne wydało rezolucję wzywającą państwa do ratyfikowania protokołów fakultatywnych do Konwencji: Protokołu fakultatywnego w sprawie angażowania dzieci w konflikty zbrojne oraz Protokołu fakultatywnego w sprawie sprzedaży dzieci, prostytucji dziecięcej i pornografii dziecięcej. Pierwszy z dokumentów nakazuje państwom - stronom podjęcie wszelkich możliwych środków, aby osoby poniżej osiemnastego roku życia nie uczestniczyły bezpośrednio w działaniach zbrojnych. Zakazano również wcielania siłą do wojska i ograniczono możliwość ochotniczego wstępowania przed uzyskaniem pełnoletniości (art. 1 i 3) ) $^{30}$. Drugi z wymienionych protokołów nakłada obowiązek wprowadzenia zakazu sprzedaży, seksualnego wykorzystywania dzieci i angażowania ich do pracy przymusowej oraz transferu ich organów dla zysków ${ }^{31}$.

\footnotetext{
${ }^{28}$ Zob. tamże; zob. J. Białocerkiewicz, dz. cyt., s. 308.

${ }^{29}$ Konwencja o Prawach Dziecka, Dz. U. z 1991 r., nr 120, poz. 526.

${ }^{30}$ Zob. Protokót Fakultatywny do Konwencji Praw Dziecka w sprawie Angażowania Dzieci w Konflikty Zbrojne, http://www.senat.gov.pl

${ }_{31}$ Zob. Protokót Fakultatywny do Konwencji Praw Dziecka w sprawie Sprzedaży Dzieci, Prostytucji Dziecięcej i Pornografii Dziecięcej; zob. także E. Czyż, dz. cyt., s. 19.
} 
Podpisano również wiele innych międzynarodowych dokumentów, mających na celu ochronę dziecka przed handlem i prostytucją. W dniu 15 grudnia 1920 roku Zgromadzenie Ligi Narodów przyjęło Rezolucję w sprawie Handlu Kobietami i Dziećmi. W Genewie 30 listopada 1921 roku została przyjęta Międzynarodowa Konwencja o zwalczaniu handlu kobietami i dziećmi ${ }^{32}$. W dniu 20 października 1947 roku została ona zmieniona Protokołem zatwierdzonym przez Zgromadzenie Ogólne Narodów Zjednoczonych. W dniu 2 grudnia 1949 roku uchwalono Konwencję w sprawie zwalczania handlu ludźmi i eksploatacji prostytucji. Strony tej Konwencji zobowiązały się do „wykonywania nadzoru nad agencjami zatrudnienia celem zapobieżenia temu, aby osoby szukające zatrudnienia, zwłaszcza kobiety i dzieci, narażone były na niebezpieczeństwo prostytucji” (art. 20) ${ }^{33}$.

Przemoc wobec dzieci, naruszenie ich praw najbardziej powszechne są w środowiskach, w których przebywają one na co dzień: w rodzinie, szkole czy na ulicy. Dziecko podlega wychowaniu nie tylko w domu, ale również w szkole. Dlatego art. 28 ust. 2 KPD zobowiązuje państwa do podejmowania „właściwych środków zapewniających, by dyscyplina szkolna była stosowana w sposób odpowiadający godności dziecka jako istoty ludzkiej”. Dyscyplina szkolna powinna kierować się opartymi na godności osoby ludzkiej międzynarodowo chronionymi prawami dziecka ${ }^{34}$.

Z przejawami szczególnej ochrony mamy do czynienia również na gruncie dokumentów dotyczących pracy dzieci. Art. 1 KPD mówi, że dzieckiem jest osoba ludzka poniżej osiemnastego roku życia. Wiek ten nie stanowi jednak progu zatrudnienia. Konieczne jest zabezpieczenie nadrzędnego interesu dziecka, a przede wszystkim ochrony przed wyzyskiem ekonomicznym (art. 3 ust. 1, art. 32 ust. 1 KPD). W art. 32. ust. 2a, b KPD mówi o nakazie ustalenia przez państwo limitów wiekowych zatrudnienia. Nakaz ten powtarzają też inne dokumenty: Międzynarodowy Pakt Praw Gospodarczych Socjalnych i Kulturalnych (art. 10 ust. 3) ${ }^{35}$, Konwencja MOP nr 138 (art. 2

${ }^{32}$ Zob. Międzynarodowa Konwencja o zwalczaniu handlu kobietami i dziećmi, Dz. U. z 1925, nr 125, poz. 893.

${ }^{33}$ Konwencja $w$ sprawie zwalczania handlu ludźmi i eksploatacji prostytucji, Dz. U. z 1952, nr 41, poz. 278 .

${ }^{34}$ Zob. Konwencja o Prawach Dziecka, Dz. U. z 1991 r., nr 120, poz. 526; zob. także B. Gronowska, T. Jasudowicz, M. Balcerzak, M. Lubiszewski, R. Mizerski, Prawa człowieka i ich ochrona, Toruń 2005, s. 381.

${ }^{35}$ Zob. Międzynarodowy Pakt Praw Gospodarczych, Socjalnych i Kulturalnych, Dz. U. z 1977, nr 38, poz. 169. 
ust. 1) $)^{36}$. Konwencja MOP nr 90 mówi również o zakazie pracy nocnej dzieci (art. 3 ust. 1$)^{37}$.

Zakazowi i eliminacji „najgorszych form pracy dzieci” poświęcona jest kolejna Konwencja MOP nr 182. Zalicza ona do nich wszelkie postacie niewolnictwa i praktyk do niego zbliżonych, w tym pracę przymusową i obowiązkową, dziecięcą prostytucję i wykorzystywanie w przemyśle pornograficznym, wykorzystywanie w działalności przestępczej, zwłaszcza handlu narkotykami oraz w innych okolicznościach, kiedy świadczenie pracy mogłoby mieć szkodliwy wpływ dla zdrowia, bezpieczeństwa i moralności dzieci (art. 3) ${ }^{38}$.

Dnia 3 czerwca 2005 r. wydano General Comment No. 6 (2005) - Treatment of Unaccompanied and separated children outside their country of origin. Uwagi ogólne stosowane są do wszystkich dzieci, które znajdują się poza krajem obywatelstwa, do dzieci opuszczonych i oddzielonych.

Wymienione dokumenty stanowią bogaty zbiór aktów prawnych, świadczących o tym, że dziecko jako istota słabsza objęta musi być szczególną ochroną. Przemoc przenika prawie wszystkie obszary życia społecznego, a jej ekspansja powoduje coraz większe zainteresowanie państw tą problematyką.

\section{Europejskie standardy dotyczące ochrony dziecka przed przemocą}

Wiele rozwiązań dotyczących ochrony dziecka przed przemocą przyjęły państwa europejskie. Europejska Konwencja o Ochronie Praw Człowieka i Podstawowych Wolności bezpośrednio nie dotyczy praw dziecka, ale praw ogólnych, z których jednak mogą również korzystać najmłodsi. Konwencja stoi między innymi na straży prawa do poszanowania życia rodzinnego (art. 8) $)^{39}$. Art. 2 Protokołu Nr 1 do Konwencji stanowi o prawie do nauki: „Nikt nie może być pozbawiony prawa do nauki. Wykonując swoje funkcje w dziedzinie wychowania i nauczania, Państwo uznaje prawo rodziców do

36 Zob. Konwencja MOP nr 138 dotyczqca najniższego wieku dopuszczenia do zatrudnienia, Dz. U. z 1978, nr 12, poz. 53.

37 Zob. Konwencja MOP nr 90 dotyczaca pracy nocnej mtodocianych w przemyśle, Dz. U. z 1968, nr 37, poz. 259.

38 Zob. Konwencja MOP nr 182 dotyczaca zakazu i natychmiastowych działań na rzecz eliminowania najgorszych form pracy dzieci, Dz. U. z 2004, nr 139, poz. 1474; zob. także B. Gronowska, T. Jasudowicz, M. Balcerzak, M. Lubiszewski, R. Mizerski, dz. cyt., s. 412-414.

39 Zob. Konwencja o Ochronie Praw Człowieka i Podstawowych Wolności, Dz. U. z 1993, nr 61, poz. 284 . 
zapewnienia wychowania i nauczania zgodnie $\mathrm{z}$ ich własnymi przekonaniami religijnymi i filozoficznymi" ${ }^{40}$. Obowiązek ten dotyczy nie tylko nauczania, ale także odnosi się do wychowania. Obejmuje również działalność wychowawczą, którą odnosimy do całej organizacji życia w szkole, włączając $\mathrm{w}$ to problemy dyscypliny szkolnej i stosowania $\mathrm{kar}^{41}$.

W Turynie 18 października 1961 roku podpisano Europejską Kartę Socjalną (EKS). Zawiera ona postanowienia dotyczące środków ekonomicznych, społecznych i prawnych, podejmowanych na rzecz poprawy bytu rodziny. Karta objęła również szczególną ochroną dzieci. Broni je przed fizycznymi i moralnymi zagrożeniami. Europejska Karta Socjalna ustanowiła również limity wiekowe zatrudnienia. Art. 7 ust. 1 zakazuje pracy osób poniżej piętnastego roku życia. Dopuszcza jednak lekką pracę, która nie szkodzi zdrowiu, moralności ani kształceniu dziecka. Art. 7 ust. 2 stanowi, że można ustalić wyższy wiek dopuszczenia do zatrudnienia w niektórych zawodach, które są uznane za niebezpieczne lub szkodliwe dla zdrowia. Bezwzględnie jest również zakazana nocna praca dzieci (art. 7 ust. 8). Nie jest to jednak przepis bezwzględny, bowiem dopuszczalne jest wykonywanie pewnych prac w porze nocnej przez osoby poniżej osiemnastego roku życia, po uprzednim określeniu tych zawodów przez ustawodawstwo krajowe. Osobom w wieku poniżej szesnastego roku życia przysługuje krótszy czas pracy (art. 7 ust. 4). Natomiast czas przeznaczony przez młodocianych pracowników na szkolenie zawodowe za zgodą pracodawcy może być traktowany jako część dnia pracy (art. 7 ust. 6). Osoby poniżej osiemnastego roku życia uprawnione są do corocznego płatnego urlopu, który trwa nie krócej niż trzy tygodnie (art. 7 ust. 7$)^{42}$.

W dniu 25 stycznia 1996 roku podpisano kolejny dokument w celu ochrony praw najmłodszych - Europejską Konwencję o Wykonywaniu Praw Dzieci. Polska ratyfikowała Konwencję w 1997 roku. Art. 1 wskazuje cel dokumentu, jakim jest: ,przyznanie dzieciom praw procesowych oraz ułatwienie ich wykonywania poprzez zapewnienie, że dzieci, osobiście albo za pośrednictwem innych osób lub instytucji, będą informowane i uprawnione do uczestnictwa w dotyczącym ich postępowaniu przed organem sądowym"43. Dzieci powinny mieć możliwość wykonywania swoich praw, w szczególności w toku postępowania w sprawach rodzinnych.

40 Protokót Nr 1 do Konwencji o Ochronie Praw Człowieka i Podstawowych Wolności, Dz. U. z 1995, nr 36, poz. 175.

${ }^{41}$ Zob. B. Gronowska, T. Jasudowicz, M. Balcerzak, M. Lubiszewski, R. Mizerski, dz. cyt., s. 387.

${ }^{42}$ Zob. Europejska Karta Socjalna, Dz. U. z 1999, nr 8, poz. 67.

${ }^{43}$ Europejska Konwencja o Wykonywaniu Praw Dzieci, Dz. U. 2000, nr 107, poz. 1128. 
Komitet Ministrów Rady Europy w dniu 10 września 1997 r. przyjął Rekomendację nr R (97) 13 pod tytułem Ochrona świadków przed wszelkimi próbami zastraszenia a prawo do obrony. Przestępstwa w rodzinie należą do specjalnej grupy, dlatego też Komitet zaleca wprowadzenie specjalnych środków w przypadku przestępczości w tym środowisku. Zwraca uwagę na odmienne traktowanie dorosłych i dzieci w celu zapewnienia ochrony szczególnych interesów dzieci w toku postępowania.

Rada Europy ogłosiła szereg innych rezolucji i rekomendacji, mających na celu ochronę małoletnich przed przemocą. Stanowią one prawne gwarancje i zabezpieczenie przestrzegania ich praw.

\section{Prawa w Polsce a ochrona praw dziecka}

Konstytucja, jako najwyższej rangi dokument w hierarchii polskich podstaw normatywnych, stoi na straży ochrony praw dziecka. Obowiązująca od 1997 roku Konstytucja RP w art. 18 stanowi: „małżeństwo jako związek kobiety i mężczyzny, rodzina, macierzyństwo i rodzicielstwo znajdują się pod ochroną Rzeczypospolitej Polskiej"44. Konstytucja nadaje rodzicom prawo do wychowywania dzieci zgodnie $\mathrm{z}$ ich przekonaniami. Wychowanie powinno uwzględniać stopień dojrzałości dziecka, wolność sumienia, wyznania oraz jego przekonania (art. 48 ust. 1). Dokument stanowi również o prawie rodziców do zapewnienia dzieciom wychowania i nauczania moralnego i religijnego (art. 53 ust. 3). Natomiast art. 72 ust. 1 zapewnia dziecku prawo do ochrony przed przemoca, okrucieństwem, wyzyskiem i demoralizacją. W innym miejscu czytamy: „nikt nie może być poddany torturom ani okrutnemu, nieludzkiemu lub poniżającemu traktowaniu i karaniu. Zakazuje się stosowania kar cielesnych" (art. 40) ${ }^{45}$. Ochrona prawna rodziny to jedna z podstawowych zasad konstytucyjnych, która jest rozwijana i konkretyzowana przez szereg ustaw szczegółowych, przede wszystkim: Kodeks Rodzinny i Opiekuńczy, Kodeks Cywilny, Kodeks Postępowania Cywilnego, Kodeks Pracy i Kodeks Karny ${ }^{46}$.

Kodeks Rodzinny i Opiekuńczy jest zasadniczym aktem prawnym, który reguluje problemy rodziny w polskim ustawodawstwie: zawieranie oraz ustawanie małżeństwa, stosunki majątkowe między małżonkami, obowiązki

${ }^{44}$ Zob. Konstytucja Rzeczypospolitej Polskiej, Dz. U. z 1997, nr 78, poz. 483.

${ }^{45}$ Tamże.

${ }^{46}$ Zob. J. Dutkiewicz, I. Pirogowicz, A. Steciwko, Ochrona prawna dziecka i rodziny (prawo polskie i standardy prawa międzynarodowego), w: A. Steciwko, I. Pirogowicz (red.), Dziecko i jego środowisko. Prawa dziecka - dziecko krzywdzone, Wrocław 2005, s. 17. 
alimentacyjne, pochodzenie dziecka, stosunki między rodzicami i dziećmi, instytucję przysposobienia, opieki oraz kurateli. Kodeks ten stanowi również główną podstawę materialno-prawną orzecznictwa sądów rodzinnych ${ }^{47}$.

Kodeks Karny (KK) wymienia szereg przestępstw przeciwko dzieciom i młodzieży. Art. $207 \mathrm{KK}$ stoi na straży bezpieczeństwa osobistego dziecka i jego prawidłowego rozwoju. Szczególnie piętnowane są przestępstwa nadużycia seksualnego. Małoletni poniżej piętnastego roku życia, niedojrzali seksualnie i niezdolni do wyrażania woli w zakresie życia seksualnego chronieni są w art. 200 ust. 1 KK przed obcowaniem płciowym i innymi czynnościami seksualnymi. Penalizowane jest również udostępnianie dziecku przedmiotów o charakterze pornograficznym (art. 202 ust. 2). Art. 202 ust. 3 dotyczy sprowadzania dziecięcej pornografii i jej rozpowszechniania. Bezwzględnie jest również zakazana eksploatacja prostytucji osób małoletnich (art. 204 ust. 3). KK ochrania również małoletnich przed wykorzystywaniem ich do upokarzających zajęć, które przynoszą korzyść materialną $(\text { art. } 104 \mathrm{KK})^{48}$.

W celu ochrony małoletnich wydano również szereg innych ustaw. Art. 15 ust. 2 Ustawy z dnia 26 października 1982 roku O wychowaniu w trzeźwości i przeciwdziałaniu alkoholizmowi ustanawia bezwzględny zakaz sprzedaży i podawania osobom do osiemnastego roku życia napojów alkoholowych (powyżej 1,5\% czystego alkoholu) ${ }^{49}$. Natomiast art. $208 \mathrm{KK}$ penalizuje drugi typ przestępstwa - rozpijanie małoletniego. Szereg przepisów prawnych ochrania również najmłodszych przed narkomanią. Ustawa z 29 lipca 2005 roku O przeciwdziałaniu narkomanii bezwzględnie zakazuje między innymi posiadania środków odurzających lub substancji psychotropowych oraz nakłaniania do użycia takiego środka lub substancji ${ }^{50}$. Ustawa z dnia 28 listopada 2003 roku O zmianie ustawy o ochronie zdrowia przed następstwami używania tytoniu i wyrobów tytoniowych chroni małoletnich przed negatywnymi skutkami palenia. Dotyczy zakazu sprzedaży wyrobów tytoniowych w placówkach lub obiektach, w których przebywają dzieci i młodzież, reklamy wyrobów tytoniowych w kinach, mediach i prasie, przeznaczonej dla najmłodszych. Celem jest wyeliminowanie dostępu

47 Tamże, s. 18; zob. także Kodeks Rodzinny i Opiekuńczy, Dz. U. z 1964, nr 9, poz. 59.

48 Zob. V. Konarska-Wrzosek, Ochrona dziecka w polskim prawie karnym, Torun 1999, s. $49-120$.

49 Zob. Ustawa o wychowaniu w trzeźwości i przeciwdziałaniu alkoholizmowi, Dz. U. z 1982, nr 35, poz. 230.

${ }^{50}$ Zob. Ustawa o przeciwdziałaniu narkomani, Dz. U. z 2005, nr 179, poz. 1485. 
do wyrobów tytoniowych osobom, które nie ukończyły osiemnastego roku $\dot{z ̇ y c i a}^{51}$.

Szczególną ochroną objęci są również małoletni, którzy podjęli pracę. Prawo pracy zabrania zatrudniać osoby poniżej piętnastego roku życia. Z przepisów Kodeksu Pracy wynikają też inne uregulowania: skrócony czas pracy, zakaz pracy w godzinach nadliczbowych i w porze nocnej ${ }^{52}$.

Kodeks Cywilny tylko pośrednio dotyczy ochrony rodziny. Zawiera jedynie przepisy dotyczące udziału małoletniego w obrocie prawnym oraz prawo spadkowe ${ }^{53}$. Natomiast Kodeks Postępowania Cywilnego zawiera regulacje mające wpływ na pozycję rodziny: ustawowe zwolnienie od kosztów sądowych dla osób, które dochodzą ustalenia ojcostwa oraz dla osób dochodzących roszczeń alimentacyjnych ${ }^{54}$.

Dziecko wymaga szczególnej opieki. Przede wszystkim powinno czuć się bezpiecznie w miejscu, w którym się wychowuje, w domu rodzinnym i szkole. Jeżeli do tych środowisk wkrada się przemoc, moralnym obowiązkiem jest zareagowanie i ochrona bezbronnych. Na straży ochrony praw dziecka, obok państwa stoi również szereg instytucji. Na mocy art. 43 KPD (Konwencji Praw Dziecka) powołano Komitet Praw Dziecka. Czuwa on nad przestrzeganiem praw KPD i bada postępy poszczególnych państw w realizacji przewidzianych w niej zobowiązań ${ }^{55}$. W Polsce natomiast działaja: Komitet Ochrony Praw Dziecka, Ogólnopolskie Pogotowie dla Ofiar Przemocy w Rodzinie oraz Rzecznik Praw Dziecka, do zadań którego należy podejmowanie działań na rzecz pełnego i harmonijnego rozwoju dziecka, ochrony małoletnich przed przemoca, okrucieństwem, wyzyskiem, demoralizacją, zaniedbywaniem oraz złym traktowaniem (art. 3) ${ }^{56}$. Uruchomiono również bezpłatny numer telefoniczny tzw. niebieską linię, na którą mogą dzwonić ofiary przemocy z prośbą o radę i pomoc ${ }^{57}$.

${ }^{51}$ Zob. Ustawa O zmianie ustawy ochronie zdrowia przed następstwami używania tytoniu i wyrobów tytoniowych, Dz. U. z 2003, nr 229, poz. 2274.

${ }_{52}$ Zob. Kodeks pracy, Dz. U. z 1974, nr 24, poz. 141.

${ }_{53}$ Zob. Kodeks Cywilny, Dz. U. z 1964, nr 16, poz. 93.

${ }^{54}$ Zob. Kodeks Postępowania Cywilnego, Dz. U. z 1964, nr 43, poz. 296; zob. także

J. Dutkiewicz, I. Pirogowicz, A. Steciwko, dz. cyt., s. 19.

${ }^{55}$ Konwencja o Prawach Dziecka, Dz. U. z 1991 r., nr 120, poz. 526.

${ }_{56}$ Zob. Ustawa o Rzeczniku Praw Dziecka, Dz. U. z 2000, nr 6, poz. 69.

${ }^{57}$ Zob. V. Konarska-Wrzosek, dz. cyt., s. 65. 


\section{Podsumowanie}

Trudno jest walczyć z przemoca, która zamyka się w murach rodzinnego domu lub szkoły. O istnieniu tej pierwszej opowiada coraz więcej osób dorosłych. Towarzyszy tym reminiscencjom poczucie wstydu, bezradności, a poczucie winy sprawia, że ofiara bardzo często boi się przyznać do krzywd, które ją spotkały w dzieciństwie ze strony dorosłych. Dzięki nagłośnianiu w mediach nadużyć, jakich dopuścili się opiekunowie (nie zawsze rodzice), coraz częściej dzieciństwo zaczyna być postrzegane jako koszmar - okres szczególnego nasilenia patologii (przemocy i nadużyć). Im głębiej sięga się w przeszłość, tym częściej ujawnia się przemoc fizyczna, psychiczna, wykorzystywanie seksualne, zaniedbywanie czy porzucanie małoletnich. Problemem staje się generalizacja problemu, jak również nadinterpretacja - co jednak nie powinno zwalniać społeczeństwa $\mathrm{z}$ ingerowania i przeciwdziałania występowaniu nadużyć wobec najmłodszych jego członków.

Wraz ze zmianami społeczno-kulturowymi zmieniały się formy i natężenie przemocy. Wersy Starego Testamentu ${ }^{58}$, Koran, mity, dostarczają wielu przykładów maltretowania nieletnich przez dorosłych ${ }^{59}$, co jednak nie powinno być nadinterpretowane, a ukazywać kontekst kulturalno-historyczny, który wskazuje kierunek dokonujących się zmian oraz kształtowania się standardów opiekuńczych i społecznych.

W ostatnich latach obserwujemy nasilenie działań ustawodawczych w celu zapobiegania przemocy i walki $z$ jej sprawcami, między innymi zwolennicy działań prewencyjnych przygotowali programy interwencyjne służące rozwijaniu wiedzy i umiejętności rodziców, stworzyli również rozbudowaną sieć wsparcia dla pokrzywdzonych (przykładem może być na przykład Niebieska Linia). Podjęto jednocześnie działania zmierzające do zmiany standardów normatywnych i społecznych, dotyczących wychowania i kształcenia dzieci. Jak się okazuje, programy pomocy nie są w jednakowym stopniu dostępne dla wszystkich rodzin, dotyczą najczęściej osób świadomych krzywd, które je spotykają. Uboższą ofertę zaproponowano rodzicom, którzy nie zdają sobie sprawy z tego, że potrzebują pomocy i mogą ją otrzymać. Istniejące programy prewencyjne często nie docierają do części poszkodowanych, a także okazują się nieskuteczne ${ }^{60}$. Podejmowanym dzia-

${ }^{58}$ Porównaj Księgi: Prz 13, 24; 23, 13; 23, 14 i in.

${ }^{59}$ Zob. B. Hołyst, Kulturowy i społeczny kontekst przestępczości wobec dzieci, w: tenże (red.), Ochrona dziecka. Teoria i praktyka, Legionowo 2005, s. 46.

${ }^{60}$ Zob. D. Daro, Zapobieganie krzywdzeniu dzieci: osiagnięcia $i$ wyzwania, „Dziecko Krzywdzone" 9 (2004), s. 40. 
łaniom mogą towarzyszyć nadużycia wobec sprawujących opiekę (czego dowodem są niedostosowane do potrzeb interwencje urzędników), występujące w obrębie instytucji (np. opiekuńczych, sądowniczych, jak i kościelnych). Aby ograniczać te problemy, nieodzowne jest społeczne monitorowanie oraz zwiększenie jawności działań podejmowanych przez większość instytucji.

Przemocy nie wolno tolerować, agresja skierowana przeciwko dziecku jest szczególnie piętnowana przez standardy międzynarodowe. Dziecko ma prawo do miłości, bezpieczeństwa, szczęścia, powinno wychowywać się wśród ludzi, którzy obdarzą je opieką i troskliwością. To jednak często puste postulaty. Dzieciństwo zbyt wielu kojarzy się z bólem, przemocą fizyczną i emocjonalna, wykorzystywaniem seksualnym. Dziecko po takich przejściach zamyka się w sobie, nie potrafi właściwie funkcjonować w społeczeństwie. Powracające w snach wspomnienia z dzieciństwa nie pozwalają zapomnieć o przeszłości nawet dorosłym.

\section{Protection of Children's Rights in View of Polish and International Standards (Summary)}

This article deals with the protection of children's rights in view of Polish and international standards. The issue is discussed with reference to a number of signed and ratified international conventions and treaties.

The article presents the evolution of law towards the protection of life and children's rights. The terms "children's rights" and "human rights" are referenced as concepts that are widely used and that have a varied context of meaning. The article analyses protection of children's rights in: legislation of general nature, standards of special nature, as well as Polish and European standards concerning the protection of children from violence.

The authors of the article try to present the protection of children from violence. They also mention such abuse-related emotions as shame, helplessness and guilt, which often make the victims scared to reveal the harm that they suffered from adults in their childhood.

They emphasize that in recent years there have been an increase in legislative action taken in order to prevent violence and to fight against its perpetrators, e.g. through prevention, intervention programs aimed at developing the knowledge and skills of parents, an extensive network of support for victims, as well as actions taken in order to change the normative and social standards concerning the upbringing and education of children. 